\title{
NIET-IDENTIEKE VERVANGING EN AFSCHRIJVING
}

\author{
door Dr. A. Heertje
}

\section{Inleiding}

De verwerving van een duurzaam produktieapparaat vereist offers. De volgtijdelijke verbizondering van deze offers wordt met de term afschrijven aangeduid. Afhankelijk van de denkbeelden die men omtrent het kostenprobleem huldigt, vat men de afschrijving op als de verdeling van een verlies over de tijd, of als de uitkomst van het onderzoek naar de samenhang tussen produktie en duurzaam produktieapparaat en de daaruit voortvloeiende kostencalculatie.

Soms wordt verondersteld, dat deze samenhang van causale aard is in die zin dat uit de aanwezigheid van de duurzame produktiemiddelen het produceren dwingend zou voortvloeien. Deze gedachtengang berust echter op een misverstand, zoals gemakkelijk kan worden aangetoond. De aanwezigheid van een produktieapparaat vormt slechts een voorwaarde voor de produktie, evenzeer als een bepaalde toestand van de bodem een noodzakelijke conditie is voor het vestigen van een bedrijf. De afschrijvingsprocedure kan dan ook niet langs theoretische weg worden afgeleid uit een vermeende causale relatie tussen de produktie en het complex van produktiemiddelen.

Dit neemt intussen niet weg, dat men in de praktijk van het bedrijfsbeleid de voor de verwerving van het duurzame produktieapparaat gedane uitgaven in de prijs van het eindprodukt terug wil zien. Het afschrijvingsvraagstuk maakt dan ook veeleer onderdeel uit van de bedrijfspolitiek dan van de bedrijfseconomische theorie. Daar een theoretisch juiste afschrijvingsmethode niet kan worden ontwikkeld, behoeft het ons - mede gezien de vele onzekere factoren waarmee de moderne bedrijfshuishouding geconfronteerd wordt - niet te verbazen, dat er vele suggesties zijn gedaan om de volgtijdelijke verbizondering uit te voeren.

In dit artikel zullen wij niet op al deze methoden ingaan. Het is slechts onze bedoeling te wijzen op de gemeenschappelijke onderstelling, die aan al deze afschrijvingsmethoden ten grondslag ligt. Voorts willen wij trachten aan te geven welke consequenties voor het afschrijvingsbeleid voortvloeien uit het laten vallen van deze fundamentele onderstelling.

\section{De onderstelling van de technische identieke vervanging}

De onderstelling die wij op het oog hebben hangt samen met het type van vervanging waarop de in de bedrijfseconomische literatuur naar voren gebrachte afschrijvingsmethoden zijn gebaseerd: de technisch identieke vervanging. Bij de berekening van de afschrijvingsbedragen wordt impliciet aangenomen, dat het huidige produktiemiddel op den duur zal worden vervangen door een nieuw produktiemiddel dat van het eerste slechts in leeftijd verschilt. Weliswaar maakt men in de bedrijfseconomie wel eens onderscheid tussen technische en economische slijtage, doch de consequenties die deze onderscheiding heeft voor het integrale afschrijvingsbeleid worden niet getrokken. Steeds neemt men de ontwikkeling van de vervangingswaarde ${ }^{1}$ ) van een produktiemiddel in ogenschouw, onafhankelijk

1) In dit artikel worde de vervangingswaarde als bedrijfspolitiek kengetal aangehouden. Zie voor een discussie omtrent dit vraagstuk: I. van der Zijpp, Vervangingswaarde en Alternatieve kosten, De Economist maart/april 1960, pagina 161 e.v. en een beschouwing van Prof. Kleerekoper onder dezelfde titel in de mei/juni aflevering van De Economist. 
van het verloop van de vervangingswaarde van de andere produktiemiddelen, waarmede het eerste in een complex samenwerkt. Aan deze handelwijze ligt de gedachte van een technisch identieke vervanging ten grondslag. $\mathrm{Nu}$ is hier tegen geen bezwaar zolang de hypothese van de technisch identieke vervanging een redelijke benadering inhoudt van het feitelijke economische en technische gebeuren in de bedrijfshuishouding. Het is heel goed denkbaar dat de techniek betrekkelijk langzaam voortschrijdt en dat een conservatief beleid een uniforme afloop van het produktieproces voor lange tijd garandeert. In dat geval krijgt de bedrijfsleiding voldoende inzicht in de huidige en toekomstige opbouw van het kostencijfer door uit te gaan van technisch identieke vervangingen. Zolang exogene ontwikkelingen het bedrijfsgebeuren onberoerd laten kan men met deze onderstelling blijven werken.

\section{De niet-identieke vervanging}

Het behoeft nauwelijks betoog dat dit vrijwel nooit het geval zal zijn. Voor praktisch elke moderne bedrijfshuishouding geldt, dat de niet-identieke vervanging tot de reële mogelijkheden behoort en men zou dan ook een grote fout maken door aan deze mogelijkheid voorbij te gaan. De vraag die al spoedig opkomt wanneer men zich verdiept in het vraagstuk van de niet-identieke vervanging is die naar de grens tussen identieke en niet-identieke substitutie van produktiemiddelen. Wij stellen voorop dat geen enkele definitie tot een scherpe afbakening van beide typen van vervanging leidt. Steeds blijft er sprake van een zekere vaagheid en alleen de concrete situatie kan dan tot een beslissing leiden.

Voor ons doel is het thans voldoende onder een niet-identieke vervanging van een produktiemiddel een zodanige vervanging te verstaan, dat de vereiste capaciteit van een of meer andere produktiemiddelen een duidelijke wijziging ondergaat. De niet-identieke vervanging brengt een wezenlijke verandering teweeg in de techniek van het produktieproces. In een extreem geval kan men zich zelfs voorstellen, dat het gehele produktieproces door een nieuw produktieproces wordt vervangen. Maar zelfs zonder aan dergelijke vergaande vervangingen van het eindprodukt te denken, is het niet moeilijk voorbeelden aan te halen van gevallen waarin het technische aanzien van het produktieproces fundamentele wijzigingen ondergaat, terwijl het eindprodukt betrekkelijk weinig van karakter verandert. De economische consequenties van deze in het oog springende gebeurtenissen van overwegend technische aard, dienen te worden nagegaan.

Het onmiddellijke gevolg van een niet-identieke vervanging is, dat men het waardeverloop van een produktiemiddel niet meer los kan zien van andere produktiemiddelen. Door de niet-identieke vervanging ontstaat er een interdependentie tussen de waardeverlopen van de onderscheidene produktiemiddelen in een bedrijfshuishouding. Het heeft dan geen zin meer over de afzonderlijke produktiemiddelen te spreken, omdat het feitelijke technische gebeuren dwingt de aandacht te concentreren op het complex van produktiemiddelen, waarbinnen zich de wijzigingen voltrekken. De afhankelijkheid die tussen de vereiste capaciteiten van de afzonderlijke produktiemiddelen ontstaat noodzaakt over te gaan van een partiële beschouwing van het waardeverloop van een produktiemiddel tot een integraal afschrijvingsbeleid.

\section{Niet-identieke vervanging en afschrijving}

Een integraal afschrijvingsbeleid dient te worden gebaseerd op een zo nauwkeurig 
mogelijke analyse van de interdependenties die in een bedrijfshuishouding het gevolg zijn van de niet-identieke vervanging. Aan de hand van een voorbeeld willen wij dit wat nader preciseren.

Het is gebruikelijk de afschrijving van de machines en de gebouwen van een bedrijf geheel onafhankelijk van elkaar te bepalen. Hierbij neemt men dan impliciet aan, dat het waardeverloop van de machines niet beïnvloed wordt door dat van de gebouwen en omgekeerd. Er is echter een niet-identieke vervanging van de machines denkbaar, waardoor aan deze hypothese niet langer voldaan is. Stel dat de technische ontwikkeling er toe leidt, dat een nieuw produktiemiddel op de markt wordt gebracht dat dezelfde functie kan vervullen als het oude, doch een geringere ruimte inneemt. Men kan dan voortaan met een kleiner gebouw volstaan. Tussen het waardeverloop van de machines en het waardeverloop van het gebouw bestaat nu een samenhang die bepaald wordt door het karakter en de concrete gedaante van de niet-identieke vervanging.

Bezien vanuit het standpunt van de bedrijfsleiding heeft het nu geen zin meer de afschrijving van deze produktiemiddelen afzonderlijk te bepalen. De afschrijvingspolitiek dient gericht te zijn op het volgen van het complex van produktiemiddelen. Naarmate de bedrijfshuishouding een meer dynamisch karakter draagt, naar die mate zal de afschrijving een integraler patroon moeten volgen. Het is de taak van de bedrijfseconomische onderzoeker in elke concrete situatic na te gaan hoe ver men hiermede moet gaan en in welke mate het nog zin heeft tot gedetailleerde cijferopstellingen te komen betreffende de offers verbonden aan het duurzame produktieapparaat. Het schatten van het toekomstige waardeverloop is immers bij identieke vervangingen al een uiterst moeilijke zaak, waarbij men ieder jaar correcties moet toepassen. Is men genoodzaakt de hypothese van de technisch identieke vervanging te laten vallen onder invloed van de hier geschetste omstandigheden, dan is het geven van een prognose van het waardeverloop een opgave, die in de regel te hoge eisen stelt aan onze voorspellende vermogens. Men moet zich er dan mede tevreden te stellen bij benadering aan te geven welke wijzigingen het produktiebeeld door niet-identieke vervangingen zal ondergaan. De volgende stap is dan de financiële consequenties te schatten. Op deze wijze kan men de prijszetting afstemmen op een redelijke vergoeding voor de offers die men in de toekomst zal moeten brengen, teneinde niet-identieke vervangingen in de bedrijfshuishouding te kunnen doorvoeren.

\section{Besluit}

In deze beschouwing is het vraagstuk van de niet-identieke vervanging aan de orde gesteld. In het bizonder zijn de consequenties van een dergelijk type van vervanging voor het afschrijvingsbeleid van een bedrijfshuishouding nagegaan. De conclusie werd getrokken dat de afschrijving zich over een groter deel van de bedrijfshuishouding zal uitstrekken, naarmate de niet-identieke vervanging een geprononceerder vorm aanneemt. Een consequente toepassing van deze gedachte betekent o.m., dat men in de prijs van het eigen produkt een vergoeding terug vindt voor de research van de bedrijven waarvan men de produktiemiddelen betrekt! 